\title{
Studies on Some Medicinal Plants Obtained from A Dry Tropical Forest with Emphasis on Their Antioxidant Properties
}

\author{
Iqbal Ansari, Deblina Maiti* \\ Dhanbad - 826015, Jharkhand, India. \\ *Corresponding author's Email: dmhellodeblina@gmail.com
}

Natural Resources \& Environment Management, CSIR-Central Institute of Mining \& Fuel Research, Barwa Road,

\begin{abstract}
Antioxidants are derivatives of vitamin $\mathrm{C}$ or beta-carotene that prevent reactions stimulated by oxygen, peroxides, or free radicals, thus and reduces the oxidative stress. They have found their way into many uses in treating several human diseases and reduces the risk of developing diseases like cancer. In view of these properties, the present study was focussed in identifying several plants possessing antioxidative properties and which were also conserved in the ex-situ park of CSIR - Central Institute of Mining and Fuel Research, Dhanbad, India. Fifteen medicinal plants including herbs, shrubs and grasses are reported in this paper, and a collective insight has been presented about their antioxidant properties and the present state of their pharmacological applications. The specific chemical constituents abundant in the leaves, roots, stems, seeds and fruits of each of these plants have also been dealt with. To report a few antioxidant pharmacological preparations from Ayurvedic literature are Vimang, Maharishi Amrit Kalash (MAK4, MAK5), Maharishi Ayurved (MA631, MA47), MA Raja's Cup, MA Student Rasayana and MA Ladies Rasayana. This review has been attempted to enhance the importance of the plants which are generally being neglected, so that it can used by the local people in rural areas for their cultivation and it will also pave the pathway for their subsequent future use in medicinal and research industry for drug formulation.
\end{abstract}

Keywords: Free Radicals; Antioxidants; Pharmacological Value; Vitamin C; Ageing; Herbs

\section{Introduction}

Oxidative stress is the result of free radicals generated from lipid oxidation products which harm healthy cells, contributing to aging and diseases like liver cirrhosis, atherosclerosis, cancer, and diabetes ${ }^{[1-4]}$. These free radicals if scavenged can help prevent such diseases. Antioxidants or derivatives of vitamin $\mathrm{C}$ are beta-carotene compounds that can scavenge these free radicals ${ }^{[5]}$. They act by delaying or inhibiting the oxidative chain reaction during oxidation of lipids $^{[6]}$ and deactivate the free radicals already generated, often before they attack targets cells ${ }^{[7]}$. Usually the antioxidants which are available in the market are found in the form of costly medicines. Many medicinal plants on the other hand possess natural antioxidants ${ }^{[8]}$ and have been exploited from ancient times in ayurveda for human benefits ${ }^{[9]}$. These antioxidants are usually classified as flavonoids, anthocyanins, cartenoids, dietary glutathionine and vitamins $^{[10-13]}$.

Various studies have been reported in literature concerning research works on many plant extracts for a significant antioxidant activity ${ }^{[14-16]}$. Phytochemical analysis of rasayana from plants showed that a large numbers of compounds including tannic acid, flavonoids, tocopherol, curcumin, ascorbate, carotenoids, polyphenols, etc. have shown effective antioxidant properties ${ }^{[17-19]}$. Govind ${ }^{[20]}$ stated that on the use of medicinal plants with high level of antioxidant constituents can be an effective therapeutic approach for treating hepatic damages. Shikhar et al. ${ }^{[21]}$ has reviewed six plants such as Lantana camara, Glycyrrhiza glabra, Vaccinium oxycoccos, Cinnamomum zeylanicum, Saraca indica and Acacia arabica for their antioxidant properties. Based on phytochemical analysis they revealed that a large number

Copyright (C) 2019 Iqbal Ansari et al.

doi: 10.24294 sf.v1i2.790

EnPress Publisher LLC.This work is licensed under the Creative Commons Attribution-NonCommercial 4.0 International License (CC BY-NC 4.0). http://creativecommons.org/licenses/ by/4.0/ 
of compounds including flavonoids along with phenolics also show antioxidant properties. Another seven medicinal plants like Ocimum sanctum, Camellia sinensis, Withania somnifera, Glycyrrhiza glabra, Curcuma longa, Zingiber officinale, Me-lia azaderach were also reported for their antioxidant potential ${ }^{[22]}$. Kusuma et al. ${ }^{[23]}$ studied the antioxidant properties of some medicinal plants used by the Bentian tribe from Indonesia for medicinal use. Antioxidant activity is mostly assayed by DPPH (diphenyl picryl hydrazyl) radical scavenging activity mechanism. The most extensive antioxidant activities against DPPH were displayed by the ethanol extracts of Ficus variegate stem bark, Leucosyke quadrinerva root and Clausena excavate leaves exhibiting $91 \%, 91 \%$ and $86 \%$ inhibition of the radicals, respectively ${ }^{[23]}$. Similarly plants such as Emblica officinalis, Curcuma longa, Mangifera indica, Momordica charantia, Santalum album, Swertia chirata, Withania somnifera were also reviewed for their antioxidant properties, phytochemical and pharmacological aspects ${ }^{[24]}$. Ferreira et al. ${ }^{[25]}$ analysed ten Portuguese plants for inhibitory activity of the enzyme acetyl cholinesterase as per their antioxidant activity. The ethanolic extract of Sanguisorba minor showed the best inhibition of $\mathrm{AChE}$ and subsequently showed a very good antioxidant activity. A decoction of Menthasu aveolens was also very effective in the inhibition of $\mathrm{AChE}$ and as a scavenger of radicals. Antioxidant properties of Laurus nobilis, Menthasu aveolens, Hypericumun dulatum, Melissa officinalis and Sanguisorba minor can help in preventing or alleviating patients suffering from AIDS as they showed both inhibitory activity on AChE. These herbs have also been used for a long time as a source of food, and condiments in Portugal but recent studies have indicated that they also have a scientific value which suggests their applications in new avenues ${ }^{[25]}$. Seven Korean medicinal plants were also studies for their free radical scavenging capacities and antioxidant activities. They observed that the root bark of Morus alba and the leaf of Saururus chinensis showed stronger SC50 or ID50 values. Their experimental result shows a protective effect on DNA damage caused by hydroxyl radicals produced from UV-induced photolysis of hydrogen peroxide ${ }^{[26]}$. Whole plant of Torilis leptophylla was studied for antioxidant properties in which the phytochemical screening such as total phenolic (TPC) and total flavonoid contents (TFC) showed radical scavenging activity. They suggested that methanolic extract of T. leptophylla may be useful in defence against CCl4-induced liver damage in male Sprague-Dawley rat possibly due to its antioxidant properties and it can be the potent source of natural antioxidants in food as well in pharmaceutical formulations ${ }^{[27]}$. Pourmorad et al ${ }^{[28]}$ showed antioxidant activity of Mellilotus officinalis plant extract and it was 4 times greater than the synthetic antioxidant called butylated hydroxy toluene (BHT). The extract of M. officinalis, showed highest amount of flavonoid and phenolic compounds, and exhibited antioxidant activity due to the hydroxyl groups existing in the phenolic compounds ${ }^{[28]}$. Thus, from various experimental studies it has been revealed that such plants can be good sources of natural antioxidants that can be further harnessed for treating different ailments.

In the state of Jharkhand various such medical plants including herbs shrubs and grasses having antioxidant property and are dominant species along the roadsides, arable and fallow lands. There is need to conserve these species at any cost. Earlier in one of our studies we had carried an ethnobotanical study to identify medicinal importance of some selected dominant species in the native forest of Jharkhand and preserved all of them under ex-situ conservation Park for socio-economic development of the tribals ${ }^{[29]}$. In the study, a total of 41 medicinal plants had been selected and documented for their therapeutic use against various types of diseases frequently occurring in tribal people in mining areas of the coal capital of India ${ }^{[29]}$. We also reviewed 23 different types of medicinal plants, herbs and shrubs dominating the Jharkhand state and which can be sustainably exploited to cure various ailments in local people who lack modern medicine facility ${ }^{[29-30]}$. In this regard, firstly, there is a necessity for developing an awareness regarding the antioxidants which are naturally available, their method of use and cultivation. This would make the use of antioxidants cost-effective and pave the pathway for future research and medicinal industry for formulationg new drugs. Thus, the aim of the study is to enhance the importance of the plants which are generally being neglected, so that it can be used for earning a livelihood in the long term.

\section{Survey study done in CSIR-CIMFR}

\subsection{Study area}


The ex-situ conservation park $\left(23^{\circ} 48^{\prime} 57.20^{\prime \prime} \mathrm{N}\right.$ and $\left.86^{\circ} 25^{\prime} 41.71^{\prime \prime} \mathrm{E}\right)$ is located at CSIR-CIMFR, Dhanbad, Jharkhand, India. The institute is located in the town of Dhanbad, known as coal capital of India. It is strategically situated in the Damodar basin of eastern part of the country which is endowed with rich coal deposits and hosts several large mineral based industries. The area experiences tropical climate and is characterized by very hot summer and cold winters. The temperature in the cold weather months (November to February) varies from lowest minimum of $8.3^{\circ} \mathrm{C}$ to the highest maximum of $34.4^{\circ} \mathrm{C}$. During summer months March to June it varies from the lowest minimum of $13.3^{\circ} \mathrm{C}$ to the highest maximum of $47.0^{\circ} \mathrm{C}$. During the remaining months, July to October, the rainy season persist in which the temperature varies from the lowest minimum $15^{\circ} \mathrm{C}$ to $36^{\circ} \mathrm{C}$. Relative humidity (RH) is high in the rainy days being about $94 \%$ in June and low in the month of May which is about 36\%. Thunder storms usually occur in the month of May and June accompanied by a temporary fall by some degrees. The area receives annual rainfall of about 1100-1200 $\mathrm{mm}$.

\subsection{Vegetation of the study area}

The dry deciduous forest was dominated by tree species such as Palash (Butea monosperma Lamb. Taub, Asan (Terminalia tomentosa Wight \& Arn), Sal (Shorea robusta Gaertn) and Shishum (Dalbergia sisoo Rujuta). The species such as Sidha (Lagerstromia parviflora Roxb.), Gamhar (Gmelina arborea Roxb. ex Sm), Sirish (Albizzia lebbeck L. Benth), Bahera (Terminalia belerica Gaertn. Roxb.), Bel (Aegle marmelos.Correa), Semal (Bombax malabaricum DC), Khair (Acacia catechu L. f. wild), Mahua (Madhuca indica G.F. Gmel) were also found scattered in the forests. However, Salai is (Boswellia serrate Roxb. ex Colebr) one of the common species in dry mixed deciduous forests in other parts of Jharkhand but was almost absent here except a few individuals. Good quality of bamboo forests was also found mixed with these trees. The species with high medicinal value from the forests were conserved in our ex-situ conservation park.

\subsection{Data collection methods}

The study was carried out at the ex-situ conservation Park which was established in the year 2003 by the Ministry of Environment and Forest (MoEF), Government of India. All plant specimens were collected during the adulthood stage with the help of gardeners, and local well-knowledged persons and identify the plants on the basis o their habit and habitat. The local names of the plants were obtained from the local habitants. The specimens were photographed, pressed and dried in the field. Samples were also taken for scientific identification and preparations of herbarium as per standard procedures ${ }^{[31]}$. The species were identified by the Botanical Survey of India; Kolkata. The socio-interaction was carried out to know its therapeutic uses and a door to door survey was done. On the basis of the various therapeutic uses of selected medicinal plants, their antioxidant properties were identified.

\section{Antioxidant properties of the selected dominant plants}

The collected data on ethno-medicinal uses as well as antioxidant properties of the selected herbs, shrubs grasses and plants is presented in Table 1. The columns include the botanical name, plant type, family, local name, parts used, and the chemical constituents used as antioxidants. The photographs of the individual plants taken during the field study have been shown in Figure 1. Namely the plants include 8 trees, 4 herbs, 2 climbers and 1 grasses. Their scientific names are Alstonia scholaris L. R. Br., Andrographis paniculata Burm. f. Wall. ex Nees, Carcum copticum Linn., Cissus quandrangularis L., Cymbopogon citratus L. DC. Ex Nees. Stapf., Mangifera indica Linn., Mimusopus elengi Linn., Ocimum sanctum Linn., Pterospermum acerifolium L., Willd Santalum album Linn., Saraca asoca Roxb. Willd., Terminalia arjuna Roxb. Wright \& Arn., Terminalia bellirica Gaertn. Roxb., Tinospora cordifolia Thunb. Miers ., Withania somnifera L. Dunal. The literature revealed that the antioxidant property of the plants were observed in the roots, leaves, stem, fruits, bark, flowers, seeds, latex as well as in whole plants in some of the species. Chemically the antioxidants extracted from the plants were alkaloids, terpenoids, diterpenoids, diterpene, flavonoids, polyphenols, glycosides, lactones, glycosides, saponins, steroids etc. These plants were also found to be abundant in the natural forests and ex-situ Conservation Park as they are native plants and adapted to the local climate. In this aspect, policies and strategies should be framed out conjointly my the Government and Research Institutes to cultivate these highly 
important medicinal plants on the vast acres of degraded lands to address various environmentally important topics like soil conservation, soil fertility, carbon sequestration, and switching to green medicine compared to chemical developed synthetic drugs in laboratories.

\begin{tabular}{|c|c|c|c|c|c|c|}
\hline $\begin{array}{l}\text { Sl. } \\
\text { no }\end{array}$ & Botanical name & $\begin{array}{l}\text { Plant } \\
\text { type }\end{array}$ & Family & Local name & Parts used & Chemical constituents \\
\hline 1. & $\begin{array}{l}\text { Alstonia scholaris } \\
\text { (L.) R.Br. }\end{array}$ & $\mathrm{T}$ & Apocynaceae & Chhatim & $\begin{array}{l}\text { stem barks, } \\
\text { flower, latex }\end{array}$ & $\begin{array}{l}\text { Alkaloids (alstonidine, } \\
\text { alstonine, chlorogenic acid, } \\
\text { chlorogenine, ditain, } \\
\text { echitamine, echitanin, } \\
\beta \text {-sitosterol), terpenoids } \\
\text { (lupeol, linoleate, lupeol), } \\
\text { flavonoids }\end{array}$ \\
\hline 2. & $\begin{array}{l}\text { Andrographis } \\
\text { paniculata Burm.f. } \\
\text { Wall, ex Nees }\end{array}$ & $\mathrm{H}$ & Acanthacea & Kalmegh & $\begin{array}{l}\text { Leaves, roots, } \\
\text { whole plants }\end{array}$ & $\begin{array}{l}\text { Diterpenoids, diterpene, } \\
\text { flavonoids, polyphenols, } \\
\text { glycosides, lactones }\end{array}$ \\
\hline 3. & $\begin{array}{l}\text { Carcum copticum } \\
\text { Linn. }\end{array}$ & $\mathrm{H}$ & Apiaceae & Ajwain & Seeds & $\begin{array}{l}\text { Terpenoids, alkaloids, } \\
\text { glycosides, flavonoids, } \\
\text { saponins, steroids }\end{array}$ \\
\hline 4. & $\begin{array}{l}\text { Cissus } \\
\text { quandrangularis } \mathrm{L} .\end{array}$ & $\mathrm{C}$ & Vitaceae & Hadjod & Stem & $\begin{array}{l}\text { Triterpenes, } \alpha \text { - and } \beta \text { - } \\
\text { amyrins, } \beta \text {-sitosterol, } \\
\text { keto-steroids, phenols, } \\
\text { carotene, vitamin C } \\
\text { flavonoids, quercetin, } \\
\text { kaempferol }\end{array}$ \\
\hline 5. & $\begin{array}{l}\text { Cymbopogon } \\
\text { citratus L. DC. Ex. } \\
\text { Nees. Stapf. }\end{array}$ & G & Poaceae & Lemon grass & Leaves, stem & $\begin{array}{l}\text { Tannins, sterols, terpenoids, } \\
\text { phenols, ketone, flavonoids, } \\
\text { alkaloids, saponin, } \\
\text { (a-sistosterol), terpenes, } \\
\text { flavonoids, cholorogenic } \\
\text { acid, p-coumaric acid }\end{array}$ \\
\hline 6. & $\begin{array}{l}\text { Mangifera indica } \\
\text { Linn. }\end{array}$ & $\mathrm{T}$ & Anacardiaceae & Aam & $\begin{array}{l}\text { Leaves, } \\
\text { fruits, barks, } \\
\text { seeds }\end{array}$ & $\begin{array}{l}\text { Flavonoid, phenolic acid, } \\
\beta \text {-carotene \& Vitamin C }\end{array}$ \\
\hline 7. & $\begin{array}{l}\text { Mimusopus elengi } \\
\text { Linn. }\end{array}$ & $\mathrm{T}$ & Sapotaceae & Bakul & $\begin{array}{l}\text { Bark, seed, } \\
\text { leaf, fruit }\end{array}$ & $\begin{array}{l}\text { Alkaloids, saponins, } \\
\text { quercitol, hentriacontane, } \\
\beta \text {-carotene, quercetin }\end{array}$ \\
\hline 8. & $\begin{array}{l}\text { Ocimum sanctum } \\
\text { Linn. }\end{array}$ & $\mathrm{H}$ & Lamiaceae & Tulsi & Leaves, seeds & $\begin{array}{l}\text { Saponins, flavonoids, } \\
\text { triterpenoids, phenolic } \\
\text { compounds, vitamin C }\end{array}$ \\
\hline 9. & $\begin{array}{l}\text { Pterospermum } \\
\text { acerifolium L. Willd. }\end{array}$ & $\mathrm{T}$ & Sterculiaceae & Kanak champa & $\begin{array}{l}\text { Leaves, bark, } \\
\text { flowers }\end{array}$ & $\begin{array}{l}\text { Flavonoids, tannins, cardiac } \\
\text { glycosides, saponin } \\
\text { glycosides, terpenoids, } \\
\text { anthraquinones, alkaloids }\end{array}$ \\
\hline 10. & $\begin{array}{l}\text { Santalum album } \\
\text { Linn. }\end{array}$ & $\mathrm{T}$ & Santalaceae & Safed chandan & Bark & $\begin{array}{l}\text { Gallic acid (polyphenol), } \\
\alpha \text {-tocopherol, quercetin }\end{array}$ \\
\hline
\end{tabular}




\begin{tabular}{|c|c|c|c|c|c|c|}
\hline & & & & & & $\begin{array}{l}\text { (flavonoid), squalene } \\
\text { (terpenoid), } \\
\text { proanthocyanidins, } \\
\text { ellagitannins, gallotannins, } \\
\text { stilbenoids, phenolic acids }\end{array}$ \\
\hline 11. & $\begin{array}{l}\text { Saraca asoca Roxb. } \\
\text { Willd. }\end{array}$ & $\mathrm{T}$ & Caesalpiniaceae & Ashok & $\begin{array}{l}\text { Bark, leaves, } \\
\text { flowers, seeds }\end{array}$ & $\begin{array}{l}\text { Ascorbic acid, catechin, } \\
\text { flavonoids, lignin } \\
\text { glycosides, } \beta \text {-sitosterol, } \\
\text { polyphenolics }\end{array}$ \\
\hline 12. & $\begin{array}{l}\text { Terminalia arjuna } \\
\text { Roxb. Wright \& Arn. }\end{array}$ & $\mathrm{T}$ & Combretaceae & Arjun & $\begin{array}{l}\text { Barks, stems, } \\
\text { leaves }\end{array}$ & $\begin{array}{l}\text { Tannins, triterpenoidsaponin } \\
\text { (arjunic acid, arjunolic acid, } \\
\text { arjungenin, arjunglycosides) } \\
\text { flavonoids (arjunone, } \\
\text { arjunolone, luteolin), gallic } \\
\text { acid, ellagic acid }\end{array}$ \\
\hline 13. & $\begin{array}{l}\text { Terminalia bellirica } \\
\text { Gaertn. Roxb. }\end{array}$ & $\mathrm{T}$ & Combretaceae & Bahera & Fruits & $\begin{array}{l}\text { Glucoside, gallic acid, ethyl } \\
\text { Gallate, chebulinic acid }\end{array}$ \\
\hline 14. & $\begin{array}{l}\text { Tinospora cordifolia } \\
\text { Thunb. Miers . }\end{array}$ & $\mathrm{C}$ & Menispermaceae & Giloe & $\begin{array}{l}\text { Root, stem, } \\
\text { leaves, whole } \\
\text { plant }\end{array}$ & $\begin{array}{l}\text { Alkaloids, diterpenoid } \\
\text { lactones, glycosides, } \\
\text { steroids, sesquiterpenoid, } \\
\text { phenolics, aliphatic } \\
\text { compounds, } \\
\text { polysaccharides }\end{array}$ \\
\hline 15. & $\begin{array}{l}\text { Withania somnifera } \\
\text { L. Dunal. }\end{array}$ & $\mathrm{H}$ & Solanaceae & Ashwagandha & Roots, leaves & $\begin{array}{l}\text { Steroidal lactones, } \\
\text { alkaloids, flavonoids, } \\
\text { cuseohygrine, anahygrine, } \\
\text { tropine, anaferine, } \\
\text { glycosides, enolide }\end{array}$ \\
\hline
\end{tabular}

Note: H: herb; S: shrub; T: tree; C: creeper; G: grass

Table 1. Description of plants observed in the study for antioxidant properties

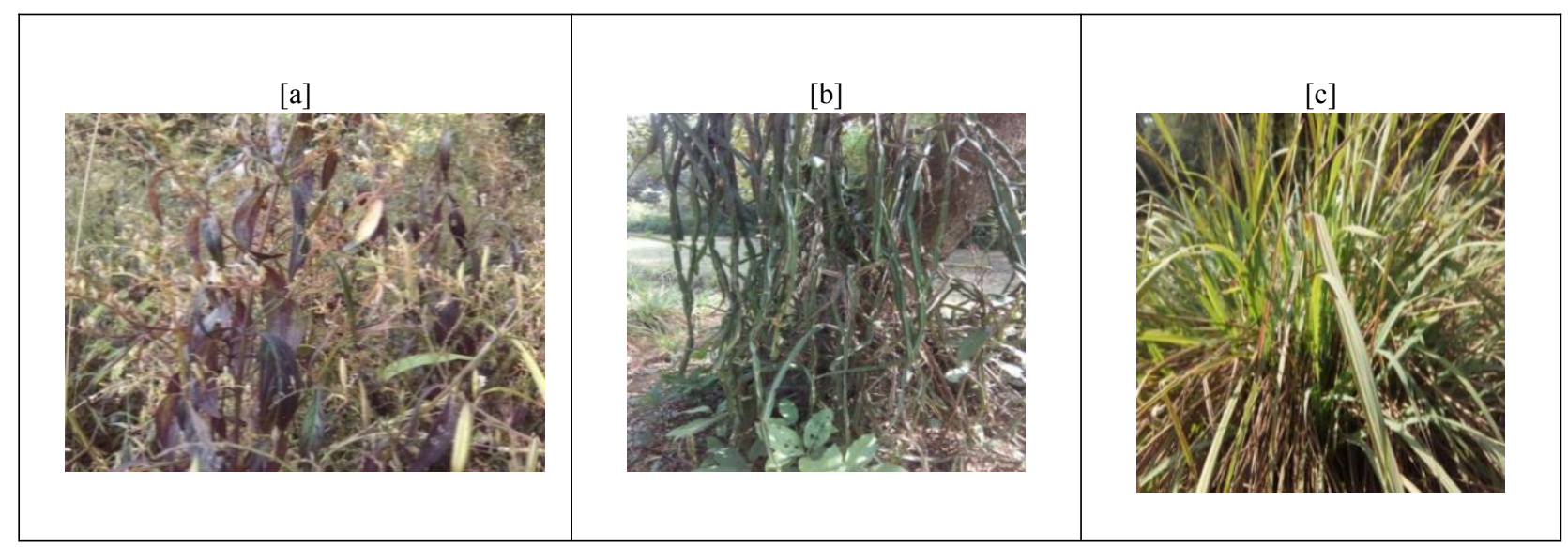




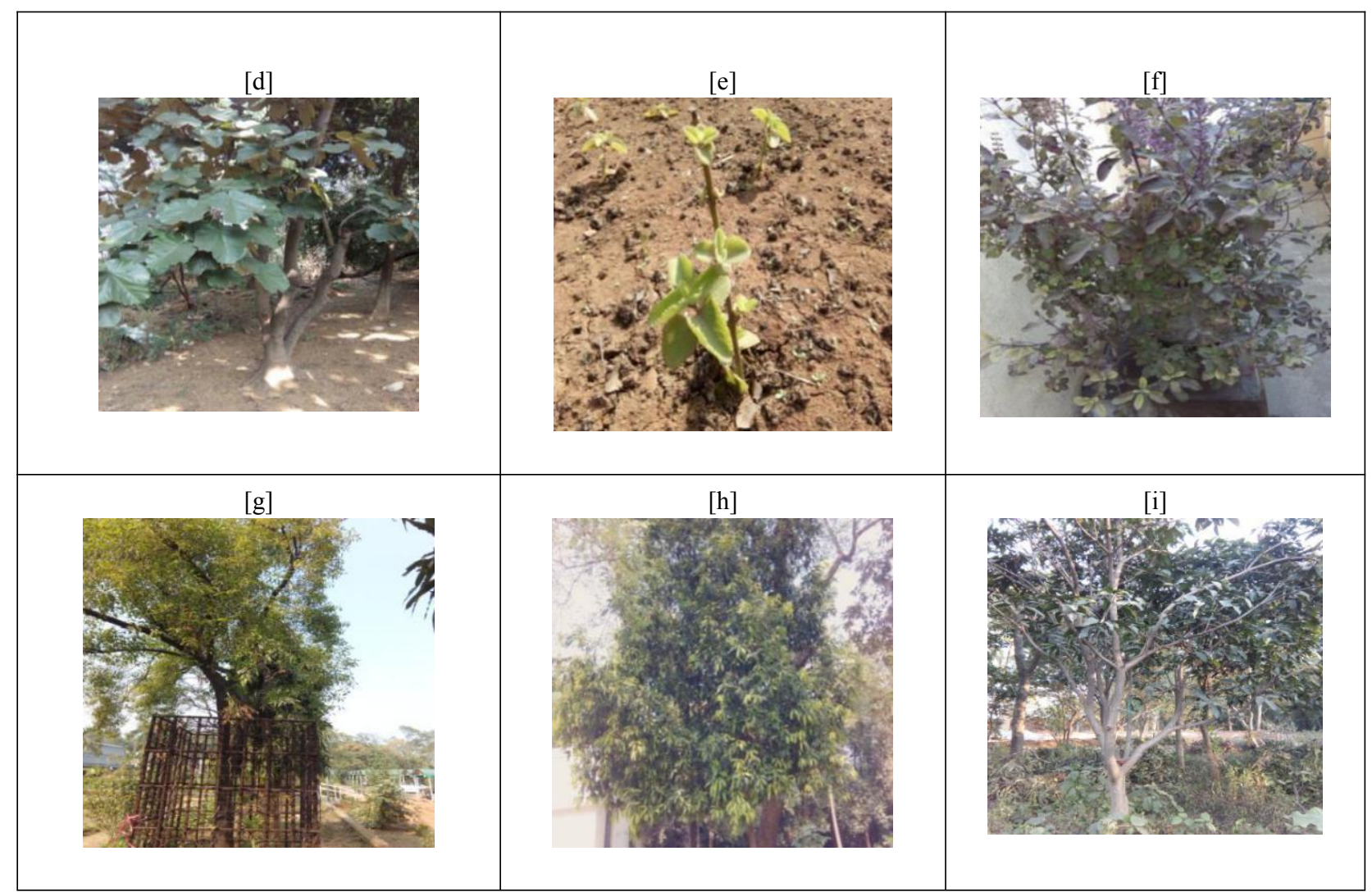

Figure 1; Pictures of the plants studied in the ex-situ conservation park, Andrographis paniculata [a]; Cissus quandrangularis [b]; Cymbopogon citratus [c]; Pterospermum acerifolium [d]; Carcum copticum [e]; Ocimum sanctum [f]; Santalum album [g]; Mimusopus elengi [h]; Mangifera indica [i].

In view of the suggestion of sustainable forestry on degraded lands by global researchers some plants have been discussed below as per the extensive work on their antioxidant properties for their future recommendation to include them in species list for establishing man-made forests tracts on barren lands. This will not only open new avenues to the drug development industry but will also add to the socio-economic status of the local people due to their value-added properties.

\subsection{Mangifera indica}

Several authors have reported $M$. indica as a potent source of antioxidants ${ }^{[32-36]}$. Chukwuemeka et al. ${ }^{[37]}$ had experimentally studied the antioxidant potential from extract $M$. indica. Their results on phytochemical screening and FTIR spectra revealed the presence of bioactive molecules including flavonoids and phenols. Bushra et al. ${ }^{[38]}$ investigated the antioxidant activity of leaves, peels, stem bark, and kernel of mango varieties Langra and Chonsa. Total phenolic (TPC) and total flavonoid contents (TFCs) in segments of Langra ranged from 63.9 to $116.8 \mathrm{mg}$ GAE/g DW and 45.6 to $90.9 \mathrm{mg} \mathrm{CE} / \mathrm{g} \mathrm{DW}$, respectively, and that of Chonsa were 69.24 to $122.60 \mathrm{mg}$ GAE/g DW and 48.43 to $92.55 \mathrm{mg} \mathrm{CE} / \mathrm{g} \mathrm{DW}$, respectively. The 2, 2-diphenyl-1-picrylhydrazyl (DPPH) scavenging activity and linoleic inhibition capacity in segments of Langra ranged from 53\% to $61 \%$ and $40 \%$ to $47 \%$, respectively, whereas for Chonsa was $56.4 \%$ to $66 \%$ and $48.1 \%$ to $49.0 \%$, respectively. Lai et al. ${ }^{[39]}$ analysed the ethanolic and aqueous extracts of $M$. indica. The standardised ethanolic extracts of the $M$. indica leaf show free radical scavenging activity of $0.17 \mathrm{mg} / \mathrm{ml}$ and a total phenolic content of $590 \mathrm{mg} / \mathrm{g}$ of extract. It proves that the aqueous and ethanolic extracts of $M$. indica leaf can protect ageing cells from oxidant-induced cell death. Similarly Ribeiro et al. ${ }^{[40]}$ has analyzed the phenolic compounds and antioxidant activities of four mango varieties cultivated in Brazil. A total of 12 flavonoids and xanthones were identified in the pulps, peels and seed kernels of the fruit with larger amounts antioxidant activity.

\subsection{Alstonia scholaris}

Molly et al. ${ }^{[41]}$ had investigated the antioxidant activity from the extracts of leaf and bark of $A$. scholaris. The 
antioxidant assays revealed the presence of tannins, proteins, phenols and steroids in the extracts. Jagetia and Baliga[42] had evaluated the cytotoxic activity of $A$. scholaris $\mathrm{R}$. Br. The highest cell killing activity was observed from the extracts prepared from the summer collections and the fractions containing the alkaloids were highly effective. Recently, in vitro radical scavenging and antioxidant activity was reported in crude alcoholic extracts of stem bark, leaves, flower and fruit ${ }^{[43-46]}$. James et a ${ }^{[47]}$ reported that the methanolic extracts of the flowers possessed higher antioxidant activity than its fruit, while the radical scavenging and antioxidant potential of the leaves was ascribed to the phenolic and flavonoid contents ${ }^{[4-45]}$.

\subsection{Andrographis paniculata}

Zhang and $\operatorname{Tan}^{[48]}$ investigated the ethanolic extracts of the aerial parts of $A$. paniculata for anti-hyperglycaemic and antioxidant effects and found that it not only possesses an anti-hyperglycaemic property, but also reduces oxidative stress in mice models. Research on the effectivity of antioxidants as well as an anti-cancerous drug Doxorubicin (DOX), in liver lymphoma indicated that the aqueous extracts of the plant is more effective than DOX with respect to its effect on catalase, superoxide dismutase, glutathione $\mathrm{S}$ transferase, lactate dehydrogenase activities ${ }^{[00]}$. Similarly Sheeja $e t$ $a{ }^{[51]}$ concluded that the methanolic extract of $A$. paniculata was found to prevent the formation of oxygen derived free radicals such as superoxide by $32 \%$, hydroxyl radicals by $80 \%$, lipid peroxidation by $80 \%$, and nitric oxide by $43 \%$.

\section{Pharmacological use of the antioxidants derived from some of the above plants}

In the present scenario various antioxidant chemical formulations from the plants are available in the market in different forms and are also being used for various medicinal purposes. Such pharmacological use/market products have been tabulated in Table 2. Descriptively M. indica has been extensively used to obtain a product known as "Vimang" which is commercially used for its antioxidant properties. Moreover various research on cancer and the need to find a cure for killing cancer cells have prompted the researchers to use the antioxidant formulations from $A$. scholaris and A. paniculata. To report some more antioxidant pharmacological preparations from Ayurvedic literature are Maharishi Amrit Kalash (MAK4, MAK5), Maharishi Ayurved (MA631, MA47), MA Raja's Cup, MA Student Rasayana and MA Ladies Rasayana.

\begin{tabular}{|l|l|l|l|}
\hline Plants & Chemical composition & $\begin{array}{l}\text { Pharmacological use/market } \\
\text { product }\end{array}$ & References \\
\hline M. indica & $\begin{array}{l}\text { Polyphenols, terpenoids, steroids, phenolic esters, } \\
\text { flavan-3-ols, xanthone (mangiferin) }\end{array}$ & Vimang & {$[52]$} \\
\hline A. scholaris & Cytotoxicity chemicals & Kills cancerous cells & {$[42]$} \\
\hline A. paniculata & Carcinogen Metabolizing Enzymes & $\begin{array}{l}\text { Has potential against } \\
\text { chemotoxicity, carcinogenicity }\end{array}$ & {$[53]$} \\
\hline
\end{tabular}

Table 2. Showing the present pharmacological use/ market product from the antioxidant chemicals derived

\section{Conclusion}

Damage caused by free radicals is responsible for development of many chronic health problems such as many cardiovascular, inflammatory diseases, cataract and cancer. Antioxidants prevent free radical induced tissue damage by preventing the formation of radicals, scavenging them, or by promoting their decomposition. Chemically the antioxidants are ascorbic acid, catechin, flavonoids, lignin glycosides, polyphenolics, alkaloids, terpenoids, tannins and carotene. Most importantly these antioxidants find their way to prevention of cancer and ageing. However the synthetic drugs and the therapies used for treating cancer or any other disease witness a myriad of side-effects. Thus, there has been an upcoming surge of shifting towards green medicine and their consumption on a daily basis/upon early diagnosis of susceptibility to a disease, as a prevention strategy for future development of the disease. In this aspect plant derived natural antioxidants resources are the only alternative which will also boost the internal antioxidating capability of a living organism. Still further detailed investigation studies are needed to justify their use as a natural 
source of antioxidants and develop commercial medicines out of them.

\section{Author Contributions}

The first author has conceived the idea of the paper. He has carried out field surveys and the socio-interaction with people to know the plant's therapeutic use. He also framed out and wrote the manuscript with the support of the coauthor and corresponding author. The second author has gone through the full manuscript and framed out the logical contents of the paper to make it more informative. She also framed out the tables, drafted the manuscript and designed the figures. All authors have conjointly discussed the findings and usefulness of the manuscript.

\section{Conflict of interest}

The authors declare no conflict of interest.

\section{Acknowledgement}

The authors want to express their sincere gratitude to Dr. Pradeep K. Singh, Director, CSIR-CIMFR, Dhanbad, Jharkhand India for the motivation during the work. The authors are also thankful to the staff members working in ex situ conservation park of CSIR-CIMFR, Dhanbad for extending their help during identification of the plants. Second author is thankful to DST (Department of Science and Technology, Government of India) for the INSPIRE (Innovation in Science Pursuit for Inspired Research) fellowship provided to her under grant number DST/INSPIRE Fellowship/2014/295.

\section{References}

1. Croft KD. Antioxidant effects of plant phenolic compounds. In T. K. Basu, N. J. Temple, \& M. L. Garg (Eds.), Antioxidants in human health and disease. New York: CABI Publishing, 1999.109-112.

2. Lemberkovics E, Czinner E, Szentmiha lyi K, et al. Comparative evaluation of Helichrysiflos herbal extracts as dietary sources of plant polyphenols, and macro- and microelements. Food Chemistry 2002; 78(1): 119-127.

3. Sami A. Oxidative stress and antioxidant defences in biology. New York: Chapman \& Hall, 1995.

4. Shon MY, Kim TH, Sung NJ. Antioxidants and free radical scavenging activity of Phellinusbaumii (Phellinus of Hymenochaetaceae) extracts. Food Chemistry 2003; 82(4): 593-597.

5. Wilson RL. Free radicals and tissue damage, mechanistic evidence from radiation studies. In: Biochemical Mechanisms of Liver Injury. Academic Press: New York 1998. 123.

6. Velioglu YS, Mazza G, Gao L et al. Antioxidant activity and total phenolics in selected fruits, vegetables, and grain products. Journal of Agricultural and Food Chemistry1998; 46(9):4113-4117.

7. Nunes PX, Silva SF, Guedes RJ et al. Biological oxidations and antioxidant activity of natural products, Phytochemicals as nutraceuticals - Global Approaches to Their Role in Nutrition and Health 2012.

8. Chanda S, Dave R. In vitro models for antioxidant activity evaluation and some medicinal plants possessing antioxidant properties: an overview. Afr J Microbiol Res. 2009; 3: 981-996.

9. Sumner J. The natural history of medicinal plants(1st ed.). Portland, Oregon, USA: Timber Press 2000.

10. Larson RA. The antioxidants of higher plants. Phytochemistry 1988;4: 969-/978.

11. Hertog MGL, Hollman PCH, Katan MB. Content of potentially anticarcinogenic flavonoids of 28 vegetables and 9 fruits commonly consumed in the Nederlands. J. Agric. Food Chem.1992; 40: 2379-2383.

12. Cao G, Sofic E, Prior RL. Antioxidant capacity of tea and common vegetables, J. Agric. Food Chem. 1996; 44: 3426-3431.

13. Kivits GAA, Vam der Sman FJP, Tijburg LBM. Analysis of catechin from green and black tea in humans: a specific and sensitive colorimetric assay of total catechins in biological fluids, Int. J. Food Sci. Nutr. 1997; 48:387-392.

14. Nagarajan, S, Jain HC, Aulakh GS. Indigenous Plants Used in the Control of Diabetes. Publication and Information Directorate CSIR New Delhi: 1987. 586.

15. Jain SR, Sharma SN. Hypoglycemic drugs of Indian indigenous origin. Planta Medica 1967; 15: 439-442.

16. Anjali P, Manoj KM. Same comments on diabetes and herbal therapy. Ancient Sci. Life 1995; 15: 27-29.

17. Gutteridge JMC. Antioxidants, nutritional supplements and life-threatening diseases. British Journal of Biomedical Science 1994; 51: 288-295.

18. Saija A, Scalese M, Lanza M, et al. Flavonoids as antioxidant agents: importance of their interaction with biomembrane. Free Radicals Biology and Medicine 1995;19 (4):481-486.

19. Van den Berg DJ. Structural aspects of antioxidant activity of flavonoids. Free Radicals Biology and Medicine 1996; 20 (3): 331-342.

20. Govind P. Medicinal plants against liver diseases. IJPR 2011; 2:115-121.

21. Shikhar K, Devendra P, Shailja G, et al. Some Indian Traditional Medicinal Plants with Antioxidant Activity: A 
Review. International Journal of Innovative Research in Science, Engineering and Technology 2013; 2(12).

22. Nigam V, Sodhi JS. Some medicinal plants with antioxidant activity- a review International Journal of pharmacy and biological sciences 2014; 4(1): 173-178.

23. Kusuma IW, Arung ET, Kim Y-u. Antimicrobial and Antioxidant Properties of Medicinal Plants Used by the Bentian Tribe from Indonesia. Food Science and Human Wellness 2014; 3(4):191-196.

24. Scartezzini P, Speroni E. Review on some plants of Indian traditional medicine with antioxidant activity. Journal of Ethnopharmacology 2000; 71: 23-43.

25. Ferreira C, Proenc MLM, Serralheiro MEM, et al. The in vitro screening for acetyl cholinesterase inhibition and antioxidant activity of medicinal plants from Portugal. Journal of Ethnopharmacology 2006; 108:31-37.

26. Chang WC, Sei CK, Soon SH, et al. Antioxidant activity and free radical scavenging capacity between Korean medicinal plants and flavonoids by assay-guided comparison. Plant Science 2002; 163: 1161-1168.

27. Saeed LN, Muhammad RK, Maria S. Antioxidant activity, total phenolic and total flavonoid contents of whole plant extracts Torilis leptophylla. BMC Complementary and Alternative Medicine 2012; 12:221.

28. Pourmorad F, Hosseinimehr SJ, Shahabimajd N. Antioxidant activity, phenol and flavonoid contents of some selected Iranian medicinal plants Afr. J. Biotechnol. 2006; 5:1142-1145.

29. Singh RS, Ansari I, Singh RK, Singh SK, et al.Medicinal plants in ex-situ conservation and its therapeutic in mine impacted lands of dry tropical forests of Jharkhand, India. Eurasian Journal of Forest Science 2017; 5(2): 44-69.

30. Ansari I, Sharma SN, Sundararajan M, et al. Medicinal plant in Jharkhand state: an overview of current scenario. Global Journal of Engineering Science and Researches 2016; 6(2):1-6.

31. Jain SK, Rao RR. Handbook of Field and Herbarium Methods. New Delhi: Goyal Offsets, 1977.

32. Sanchez GM, Re L, Giuliani A, et al Protective effects of Mangifera indica L. extract, mangiferin and selected antioxidants against TPA-induced biomolecules oxidation and peritoneal macrophage activation in mice. Pharmacological Research2000; 42: 565-573.

33. Muruganandan S, Gupta S, Kataria M, et al. Mangiferin protects the streptozotocin-induced oxidative damage to cardiac and renal tissues in rats. Toxicology 2002;176:165-173.

34. Leiro JM, Alvarez E, Arranz JA, et al. In vitro effects of mangiferin on superoxide concentrations and expression of the inductible nitric oxide synthase, tumor necrosis factor- $\alpha$ and transforming growth factor- $\beta$ genes. Biochemical Pharmacology 2003; 65: 1361-137.

35. Stoilova I, Gargova S, Stoyanova A, et al .Antimicrobial and antioxidant activity of the polyphenol mangiferin. Herbal Polonica 2005; 51:37-44.

36. Wauthoz N, Balde A, Balde ES, et al. Ethnopharmacology of Mangifera indica L. Bark and Pharmacological Studies of its Main C-Glucosylxanthone, Mangiferin. International Journal of Biomedical and Pharmaceutical Sciences 2007; 1(2): 112-119.

37. Chukwuemeka PA, Cynthia AU, Nwamaka HI, et al. In vitro antisickling, antimicrobial and antioxidant potentials of extracts of Sorghum bicolor (L) Moench seeds and Mangifera indica (L) Anacardiaceae leaves and their formulations. Journal of Science and Practice of Pharmacy 2016; 3 (1): 135-144.

38. Bushra S, Zaib H, Muhammad A, et al.Investigation on the Antioxidant Activity of Leaves, Peels, Stems Bark, and Kernel of Mango (Mangifera indica L.) Journal of Food Science 2012; 77(8).

39. Lai TL, Su AY, Ammu KR, et al.Standardised Mangifera indica extract is an ideal antioxidant. Food Chemistry 2009; 113:1154-1159.

40. Ribeiro SMR, Barbosa LCA, Queiroz JH, et al .Phenolic compounds and antioxidant capacity of Brazilian mango (Mangifera indica L.) varieties. Food Chemistry 2008; 110:620-626.

41. Molly A, Darsan BM, Joel J, et al. Phytochemical analysis and antioxidant activity of Alstonia scholaris Pharmacognosy Journal 2011;3(26):13-18.

42. Jagetia GC, Baliga MS. The effect of seasonal variation on the antineoplastic activity of Alstonia scholaris R. Br. in HeLa cells. Journal of Ethnopharmacology 2005; 96: 37-42.

43. Arulmozhi S, Mazumder PM, Ashok P, et al. In Vitro Antioxidant and free radical scavenging activity of Alstonia scholaris Linn. R. Br. Iran.J. Pharmacol. Ther. 2007; 6:191-196.

44. Ravi SK, Ramesh, KVRNS, Naveena P. Free radical scavenging activity of the flower and fruit extracts of Alstonia scholaris. Biosci. Biotechnol. Res. Asia 2008; 5:493-494.

45. Kumar A, Kaur R, Arora S. Free radical scavenging potential of some Indian medicinal plants. J. Med. Plants Res 2010; 4: 2034-2042.

46. Arulmozhi S, Mazumder PM, Narayanan LS, et al. In vitro antioxidant and free radical scavenging activity of fractions from Alstonia scholaris Linn. R. Br. Int. Journal of Pharm Tech Res 2010; 2: 18-25.

47. James J, Thaliyil V, Kumar AK, et al. In vitro antioxidant activity of flowers and fruits of Alstonia scholaris. Int. J. Phytomed. 2011;3: 475-479.

48. Zhang XF, Tan Benny KH. Antihyperglycaemic and anti-oxidant properties of andrographis paniculata in normal and diabetic rats. Clinical and Experimental Pharmacology and Physiology 2000; 27:358-363. 
49. Verma N, Vinayak M. Antioxidant action of Andrographis paniculata on lymphoma. Mol Biol Rep 2008; 35:535-540

50. Trivedi NP, Rawal UM. Hepatoprotective and antioxidant property of Andrographis paniculata Nees in BHC induced liver damage in mice. Indian J Exp Biol 2001;39: 41-6.

51. Sheeja K, Shihab PK, Kuttan G. Antioxidant and anti-inflammatory activities of the plant Andrographis paniculata Nees. Immunopharmacol Immunotoxicol 2006; 28:129-40.

52. Rodeiro I, Cancino L, Gonzalez JE, et al. Evaluation of the genotoxic potential of Mangifera indica L. extract (Vimang), a new natural product with antioxidant activity. Food and Chemical Toxicology 2006; 44: 1707-1713.

53. Singh RP, Banerjee S, Rao RA. Modulatory Influence of Andrographis paniculata on Mouse Hepatic and Extrahepatic Carcinogen Metabolizing Enzymes and Antioxidant Status Phytother. Res. 2001; 15: 382-390. 